\title{
PELATIHAN MEMBUAT MEDIA PEMBELAJARAN DENGAN APLIKASI ULEAD VIDEO STUDIO 11 BAGI GURU SMP DAN MAHASISWA KOTA LUBUKLINGGAU
}

\author{
${ }^{1}$ Agus Susilo, ${ }^{2}$ Ratna Wulansari \\ 1,2STKIP PGRI Lubuklinggau, Lubuklinggau, Indonesia \\ Email: agussusilo4590@gmail.com
}

(Diterima: 10 September 2021; Direvisi: 23 September 2021; Dipublikasikan: November 2021)

\begin{abstract}
Abstrak
Di era globalisasi ini, guru dan mahasiswa harus terbiasa dalam menggunakan atau memanfaatkan aplikasi online maupun offline untuk menunjang aktivitas pembelajaran. Dalam pelaksanaan kegiatan pengabdian kepada masyarakat ini, tim pelaksanaan kegiatan menggunakan metode secara langsung atau tatap muka. Jadi peserta kegiatan langsung mendengarkan pemaparan dan praktik untuk mendesain media dengan aplikasi Ulead Video Studio 11. Kegiatan pengabdian kepada masyarakat ini dilaksanakan disebuah Ruko di jalan Simpang Priuk Kota Lubuklinggau selama 2 hari pelaksanaannya. Hasil dari kegiatan pengabdian kepada masyarakat ini adalah selama kegiatan berlangsung Guru dan mahasiswa yang mengikuti kegiatan, dibimbing oleh pemateri yang sudah memiliki pengalaman dalam menggunakan aplikasi Ulead Video Studio 11. Selain itu, peserta juga telah membawa perlengkapan sendiri, berupa Laptop dan paket data untuk mencari materi yang akan dipergunakan dalam kegiatan pelatihan. Pelaksaan kegiatan pengabdian kepada masyarakat yang dilaksanakan selama 2 hari ini, meliputi install aplikasi, mengenalkan kegunaan Ulead Video Studio 11, dan convert menjadi media pembelajaran MP4. Kegiatan ini diakhiri dengan foto bersama pemateri dan peserta kegiatan pengabdian kepada masyarakat. Simpulannya adalah pelatihan membuat media pembelajaran dengan aplikasi Ulead Video Studio 11 bagi Guru SMP dan mahasiswa Kota Lubuklinggau sangat memberikan manfaat dan pengalaman bagi para peserta kegiatan. Para peserta yang merupakan guru dan mahasiswa dapat menerapkannya dalam kegiatan yang menyangkut pembelajaran. Selain sederhana, penggunaan aplikasi Ulead Video Studio 11, dapat digunakan secara offline tanpa jaringan internet.
\end{abstract}

Kata Kunci: Pelatihan, Ulead Video Studio 11

\begin{abstract}
:
In this era of globalization, teachers and students must be accustomed to using or utilizing online and offline applications to support learning activities. In the implementation of this community service activity, the activity implementation team uses direct or face-to-face methods. So the activity participants directly listened to the presentation and practice for designing media with the Ulead Video Studio 11 application. This community service activity was carried out in a shophouse on Jalan Simpang Priuk, Lubuklinggau City for 2 days. The result of this community service activity is that during the activity, teachers and students who take part in the activity are guided by presenters who already have experience in using the Ulead Video Studio 11 application. In addition, participants have also brought their own equipment, in the form of laptops and data packages to find materials that will be used in training activities. The implementation of community service activities carried out for 2 days, including installing applications, introducing the use of Ulead Video Studio 11, and converting them into MP4 learning media. This activity ended with a photo with the presenters and participants in community service activities. The conclusion is that the training to make learning media using the Ulead Video Studio 11 application for junior high school teachers and students in Lubuklinggau City is very beneficial and provides experience for the participants of the activity. The participants who are teachers and students can apply it in activities related to learning. Besides being simple, the use of the Ulead Video Studio 11 application can be used offline without an internet network.
\end{abstract}

Keywords: Training, Ulead Video Studio 11 


\section{PENDAHULUAN}

Berkembangnya program pendidikan di Indonesia bermanfaat bagi dunia pendidikan Untuk itu, guru maupun calon guru harus mau mengembangkan diri, agar dapat menaikan taraf pendidikan di Sekolah. Dalam pelaksaan pembelajaran di era globalisasi seperti saat ini, media menjadi primadona dalam peningkatan pembelajaran. Hampir semua generasi muda dan kalangan pendidik telah mengenal teknologi. Para guru dan siswa biasanya menggunakan laptop dan dapat dikoneksikan kejaringan internet. Media yang dikembangkan oleh guru pada dasarnya dapat meningkatkan motivasi dan semangat dalam pembelajaran di kelas maupun melalui pembelajaran jarak jauh (Wulandari, Ika, 2015). Dalam kurikulum 2013 sendiri, guru memiliki peran tidak hanya mendidik siswa menjadi pintar ilmu pengetahuan, namun juga cerdas pada akhlak yang dapat mempengaruhi kehidupan dimasyarakat. Untuk itu, di era teknologi, guru harus pandai dalam mengoperasikan komputer dan mendesain media pembelajaran (Ardiansyah, 2020).

Menurut Bibi dalam (Hasan, 2019), teknologi hasil dari kemajuan zaman tidak menggantikan peran guru dalam mengajar, namun berusaha untuk membantu guru untuk berkreasi dalam media pembelajaran. Adanya media yang didesain oleh guru dapat memudahkan dalam menjelaskan materi pelajaran. Media dengan mudah dapat didesain kapan dan dimanapun oleh guru. (Haryadi et al., 2021) sebuah media yang dapat digunakan bisa berupa website maupun aplikasi yang di akses melalui perangkat elektronik yang terhubung dengan internet. Maka, media pembelajaran sendiri dapat berupa materi pelajaran yang didesain semenarik mungkin dan dapat ditambahkan semangat melalui cara-cara mengajarnya guru. Maka jika ini diterapkan, akan menjadikan siswa mudah memahami materi pelajaran yang sedang dilaksanakan. Pembelajaran dengan menggunakan laptop atau komputer yang didukung oleh jaringan internet saat ini sangat bagus untuk dilaksanakan. Untuk lebih memudahkan dalam pembelajaran, saat ini juga dapat melalui alat bantu lainnya, seperti Smartphone yang memberikan banyak manfaat dan modernnya. Pada dasarnya teknologi komputer yang dihadirkan dalam proses pembelajaran akan meningkatkan kemampuan berpikir siswa (Sriyanti, ida, 2015).

Mahasiswa STKIP PGRI Lubuklinggau adalah mahasiswa yang aktif dan kreatif dalam mengikuti perkuliahan. Saat masa pandemik, perkuliahan online dilakukan dari rumah masingmasing. Maka saat menjelang perkuliahan semester berakhir dilakukan banyak evaluasi salah satunya penerapan media dalam pembelajaran yang dirasa cocok untuk diterapkan. Mahasiswa STKIP PGRI Lubuklinggau saat dilakukan observasi merasa memiliki keinginan untuk dapat mampu mendesain media dalam rangka persiapan mendesain media saat nanti digunakan. Pada dasarnya mendesain media yang mudah dan murah. Maka atas dasar hal tersebut kegiatan pelatihan dengan aplikasi Ulead Video Studio 11 yang terkait pelatihan media dapat terlaksana dengan baik.

Pengabdian pada masyarakat ini pada dasarnya dilakukan untuk menambah wawasan dan bakat mahasiswa dalam mendesain media dengan aplikasi Ulead Video Studio 11 maupun aplikasi lainnya. Pelatihan yang dilakukan ini dapat diterapkan mahasiswa kedepan dalam 
mengikuti kegiatan karya ilmiah mendesain media maupun saat menghadapi skripsi dengan memanfaatkan media atau bahkan mendesain media pembelajaran untuk diterapkan dalam penelitian. Atas dasar kebutuhan mahasiswa dan juga analisis situasi yang jelas bahwa pelatihan editing media dengan Ulead Video Studio 11 sangat perlu, maka dilakukan pelatihan dengan pesertanya adalah mahasiswa STKIP PGRI Lubuklinggau dengan judul "Pelatihan Mendesain Media Pembelajaran Dengan Aplikasi Ulead Video Studio 11 dan Aplikasi Sejenisnya Bagi Mahasiswa STKIP-PGRI Lubuklinggau".

Sebagai Dosen yang terus belajar dalam mendesain media maupun aplikasi, kami tim pengabdian kepada masyarakat merasa tergugah hatinya untuk membagi keilmuan kami kepada para mahasiswa. Akhirnya setelah berdiskusi dengan rekan-rekan tim pengabdian kepada masyarakat, maka disepakati media yang akan diajarkan dalam media editing video pembelajaran yang mudah untuk dipelajari yaitu media Ulead Video Studio 11. Sebenarnya media editing bukan harus semata-mata dengan menggunakan Ulead Video Studio 11. Memanfaatkan Smartphone pun dapat digunakan dalam mendesain media. Semua itu tergantung minat dan kemampuan masing-masing peserta dalam mengikuti pelatihan ini.

Hasil akhir pengabdian pada masyarakat tentang "Pelatihan Mendesain Media Pembelajaran Dengan Aplikasi Ulead Video Studio 11 dan Aplikasi Sejenisnya Bagi Mahasiswa STKIP-PGRI Lubuklinggau" ini dapat menjadi solusi bagi mahasiswa untuk terus mengembangkan dirinya dalam mengembangkan pelatihan tersebut. Mahasiswa menjadi lebih aktif dan kreatif karena mahasiswa juga dapat belajar dari berbagai sumber lain yang sesuai bidang kajiannya. Mengikuti pelatihan mendesain media yang dilakukan Dosen STKIP PGRI Lubuklinggau ini semoga dapat berdampak pada hal yang baik bagi guru dan mahasiswa sebagai calon guru saat ini. Selanjutnya, kegiatan pengabdian kepada masyarakat ini juga dapat memotivasi Dosen-Dosen lain dalam membuat kegiatan serupa khususnya bagi komunitas atau masyarakat lain yang membutuhkan sebuah pelatihan yang memang dibutuhkan dan memberikan manfaat bagi masyarakat luas.

\section{METODE}

\section{Metode Pelaksanaan}

Kegiatan pengabdian kepada masyarakat ini, dilaksanakan dengan diawalli dengan memberikan ceramah dalam bentuk workshop kepada mahasiswa STKIP PGRI Lubuklinggau yang mengikuti pelatihan secara langsung. Oleh karena situasinya pada masa Pandemik, kegiatan ini dilakukan dengan tetap menaati protokol kesehatan dan peserta di batasi. Pada saat pelaksanaan pelatihan tersebut, peserta berjumlah 15 orang peserta pelatihan yang terdiri dari guru dan mahasiswa di Kota Lubuklinggau. Pelatihan ini dilakukan selama 2 hari, yaitu hari rabu dan kamis tanggal 11-12 November 2020 di gedung ruko Simpang Priuk Lubuklinggau. Hari pertama para mahasiswa yang mengikuti pelatihan, mendengarkan pemaparan dan menginstall aplikasi Ulead Video Studio 11. Pada saat pertemuan pertama ini, peserta juga menginstall aplikasi KineMaster di Smartphonenya sebagai media editing yang ada di Hanphone.

Hari kedua, peserta pelatihan mulai mengoperasikan aplikasinya secara bergantian 
dengan Laptop untuk aplikasi Ulead Video Studio 11 dan KineMaster pada Smartphone. Para peserta pelatihan ini dibimbing dengan sabar oleh tim pengabdian kepada masyarakat dengan cara-cara mendesain yang menarik dan dapat dikembangkan. Hari kedua ini adalah mahasiswa harus mampu untuk menjadikan media yang telah didesain dapat dilihat masyarakat umum. Pelatihan hari kedua memakan waktu yang panjang, namun semua mahasiswa menikmatinya dengan baik dan sebagian besar mulai memahami dan mampu mendesain mandiri. Antusias mahasiswa STKIP PGRI Lubuklinggau dalam mengikuti pelatihan ini sangat besar. Sampai akhirnya pelatihan ini diakhiri dengan selesainya tugas mendesain oleh peserta pelatihan.

Dalam pelaksanaan pelatihan mendesain media pembelajaran dengan aplikasi Ulead Video Studio 11 dan aplikasi sejenisnya bagi mahasiswa STKIP-PGRI Lubuklinggau ini dilaksanakan dengan melibatkan sebagian peserta dari kalangan guru dan mahasiswa yang ada di kota Lubuklinggau. Pelatihan ini jelas untuk memberikan pengalaman baru bagi generasi milenial terkait editing video pembelajaran secara teoritis melalui kegiatan pengabdian kepada masyarakat. Kemudian untuk membahas hal yang lebih jelas, pemateri melakukan diskusi kepada peserta disela-sela acara pelatihan. Kegiatan diskusi dilakukan untuk menambah pengetahuan peserta kegiatan yang belum memahami pelatihan tersebut. Selanjutnya peserta kegiatan pelatihan diharapkan untuk lebih aktif dan kreatif dalam memanfaatkan kemampuannya mendesain media pembelajaran.

\section{Evaluasi}

PKM yang dilaksanakan ini tentunya mendapatkan hasil yang harus dievaluasi secara umu sesuai target yang telah ditetapkan diawal, mulai dari perencanaan kegiatan, survey ke lokasi sampai kegiatan berlangsung. Mahasiswa yang akan mengikuti kegiatan pengabdian kepada masyarakat berupa pelatihan sangat besar namun kami tim pelaksana membatasi sesuai aturan pemerintah. Banyak sekali diskusi terkait media pembelajaran dan mendesainnya agar terlihat menarik ini yang menghasilkan banyak argumen positif yang membangun. Kendala yang dihadapi dimasa pandemik dalam memaparkan pelatihan ini dilakukan tetap menjaga protokol kesehatan dan tetap semangat dalam melaksanakan tri darma perguruan tinggi. Pada dasarnya mahasiswa sangat antusias dengan kehadiran kami tim pengabdian kepada masyarakat yang telah memberikan pelatihan mendesain media pembelajaran.

Kendala lain adalah anggaran yang tim pelaksana gunakan sangat kurang. Tim pelaksana mengunakan dana pribadi hasil iuran. Keinginan pelaksanaan secara online untuk mendapatkan peserta yang banyak terkendala dana yang dimasa pandemik ini kurang memadai. Berbagai kendala yang menjadi masalah dalam kegiatan pengabdian kepada masyarakat ini dapat teratasi dengan baik dan kegiatan pengabdian kepada masyarakat terlaksana sebagaimana mestinya. Kedepan dukungan lembaga STKIP PGRI Lubuklinggau sangat diperlukan sekali dan tentunya dengan materi pelatihan yang terupdate dan lebih luas lagi. Oleh karena keterbatasan biaya tersebut pelatihan ini hanya melibatkan sebagian kecil mahasiswa dan dilaksanakan secara langsung. 


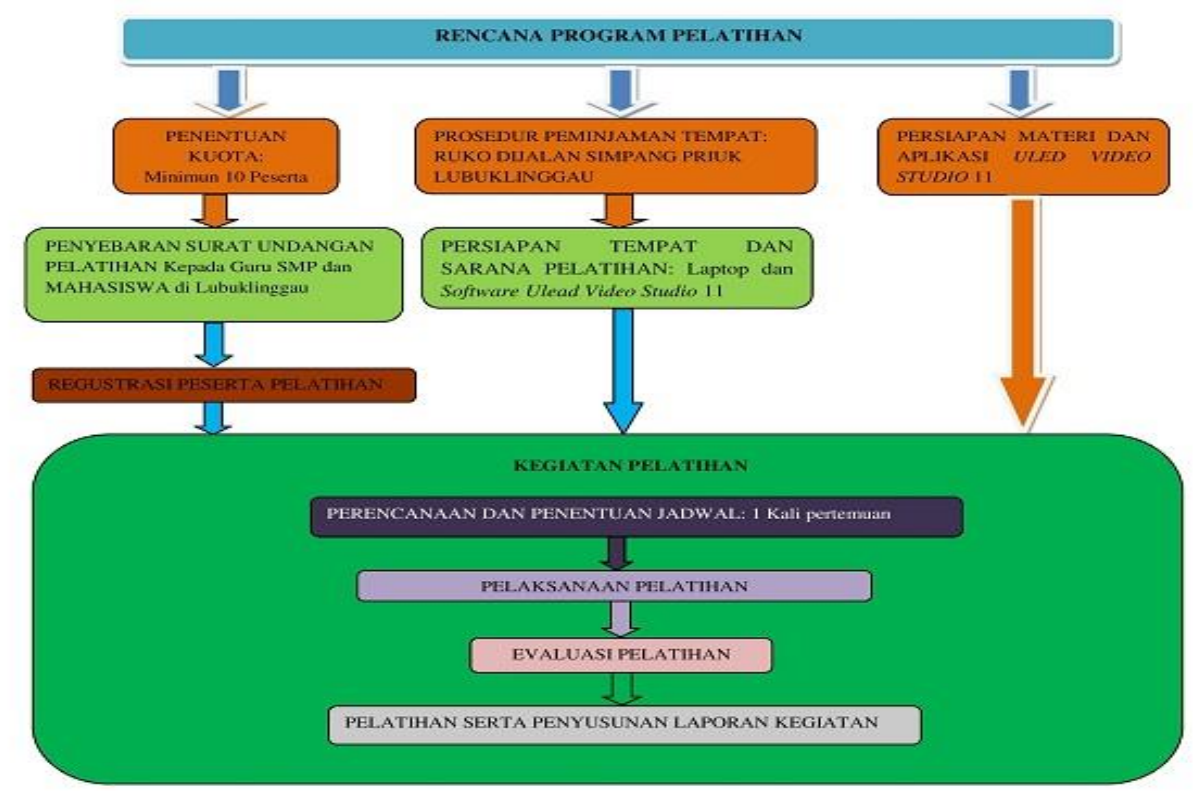

Bagan 1. Kerangka Program Kegiatan Pelatihan

\section{HASIL DAN PEMBAHASAN}

Tahapan pelatihan kegiatan pengabdian kepada masyarakat dengan judul Pelatihan Mendesain Media Pembelajaran Dengan Aplikasi Ulead Video Studio 11 dan Aplikasi Sejenisnya Bagi Guru SMP dan Mahasiswa STKIP-PGRI Lubuklinggau ini disekapati dilaksanakan di ruko Simpang Priuk Kota Lubuklinggau atas dasar pertimbangan mudah dijangkau dan tidak terlalu ramai oleh masyarakat. Pemilihan tempat tempat tersebut, didasari oleh kesepakatan bersama antara Dosen dan mahasiswa sebagai mitra pengabdian kepada masyarakat. Pelatihan ini dilaksanakan selama dua hari yang dalam dua hari tersebut peserta melaksanakan pelatihan langsung dengan dibimbing tim pelaksana pengabdian kepada masyarakat. Hari pertama kegiatan berupa pengenalan media editing video Ulead Video Studio 11 dan media, serta selanjutnya peserta menginstall aplikasi tersebut. Hari pertama sendiri tim pelaksana sebelum menutup pelatihan hari pertama memberikan tugas kepada peserta untuk menyiapkan gambar dan video singkat tentang sejarah yang diunduh di google. Hari kedua peserta dengan dibimbing tim pengabdian kepada masyarakat melaksanakan kegiatan langsung dengan mendesain media melalui Ulead Video Studio 11.

Hari kedua ini memiliki durasi yang sangat panjang, yang dimulai dari pagi hari sampai sore hari. Para peserta sangat antusias dalam mengikuti kegiatan tersebut dengan penuh semangat yang tinggi. Para peserta dengan keseriusan dalam mengikuti kegiatan dengan penuh kesabaran terus mendesain media pembelajaran melalui aplikasi Ulead Video Studio 11. Para peserta mendesain media pembelajaran dengan dua aplikasi sekaligus dan saling membagi waktu. Saat menjelang waktu isoma, pelatihan diistirahatkan untuk makan dan melaksanakan kegiatan ibadah. Waktu isoma sekitar satu jam yang digunakan sebaik-baiknya oleh para peserta. Saat waktu isoma telah selesai peserta kembali mengikuti pelatihan dan meneruskan 
kegiatan yang sebelumnya tertunda. Semangat para peserta pelatihan sangat luar biasa sekali. Pelatihan yang diikuti secara serius ini juga menghadirkan diskusi dan canda tawa saat proses mendesain media pembelajaran. Saat pembuatan media telah memasuki masa akhir, peserta selanjutnya menshare media menjadi MP4 agar dapat ditonton bersama-sama. Sesi menshare media ini memakan waktu tergantung video yang ada di media tersebut. Waktu menshare media menjadi MP4 ini \pm 1 jam. Para peserta sangat antusias dan sangat senang melihat karyanya telah berhasil dengan baik.

Sebagai pemateri dan pembimbing pelatihan ini, tim pelaksana pengabdian kepada masyarakat kami sangat senang sekali dengan hasil yang didapatkan peserta yang rata-rata mampu menyelesaikan dengan sempurna. tim pelaksana pengabdian kepada masyarakat. Tim pelaksana pengabdian kepada masyarakat juga berpesan kepada para peserta untuk aktif mengikuti kegiatan serupa yang mampu mengembangkan dirinya. Peserta diharapkan juga tidak mudah berpuas diri setelah mampu mendesain media pembelajaran dengan baik. Bagi peserta yang telah mampu mendesain media pembelajaran untuk tetap belajar dan terus mengembangkan diri. Peserta dapat mengajari rekan dan temannya yang belum berhasil membuat media pembelajaran dengan sempurna. Kedepan harapan kami kegiatan serupa dapat dilakukan dan memotivasi dosen-dosen lainnya untuk memberikan pengalamannya kepada peserta yang membutuhkan. Tetap menjaga kekompakan dan menjaga kesehatan dari wabah pandemi saat ini.

Dari hasil pelaksanaan kegiatan pengabdian kepada masyarakat dengan judul: pelatihan mendesain media pembelajaran dengan aplikasi Ulead Video Studio 11 dan aplikasi sejenisnya bagi mahasiswa STKIP-PGRI Lubuklinggau ini terlaksana dengan baik dan mendapatkan respon yang positif dari pada peserta yang mengikuti pelatihan dan sesuai target yang ditetapkan tim pengusul. Baik ditinjau dari sisi target peserta, isi, atau materi, maupun target waktu yang ditetapkan dan direncanakan di awal kegiatan. Harapan tim pelaksana pengabdian kepada masyarakat, kegiatan seperti ini dapat dilanjutkan kembali di masa yang akan datang agar menambah wawasan para peserta pelatihan.

Kegiatan pengabdian ini diawali dengan tahap observasi langsung kebutuhan akan pelatihan media pembelajaran bagi kalangan mahasiswa STKIP PGRI Lubuklinggau. Berdasarkan hasil diskusi dengan mahasiswa dan melihat prospek kedepan pelatihan mendesain media ini akhirnya secepatnya dilaksanakan. Saat akan dilaksanakan pelatihan sendiri, keadaan Lubuklinggau sedang mengalami masa pandemik yang mana saat itu kegiatan yang mengumpulkan orang banyak dilarang. Maka dengan mengikuti protokol kesehatan, pelatihan dilaksanakan secara tertutup dan peserta dibatasi. Pelatihan ini melibatkan dua Dosen Pendidikan Sejarah yang memiliki kemampuan mendesain media pembelajaran dan juga memiliki kemampuan dalam menelaah materi yang terkandung dalam media pembelajaran tersebut. Peserta pelatihan sendiri sebelumnya telah diberi tahu bahwa harus membawa kelengkapan berupa Laptop dan Smartphone serta kabel untuk menghubungkan arus listrik dengan perlengkapan tersebut. Selain itu, peserta juga harus memakai masker dan membawa Hansanitaizer. Peserta dalam ruangan telah diatur untuk saling menjaga jarak satu sama lainnya. 
Media adalah alat yang dapat menunjang dalam berbagai aktivitas kehidupan yang dilakukan oleh para pengguna media tersebut. Media pembelajaran sendiri berarti alat yang dipergunakan dalam menunjang sistem pembelajaran di Sekolah. Media pembelajaran berguna untuk membuka pemikiran siswa dan membuat jalannya diskusi antar siswa terjadi pada saat digunakan sebagai media pembelajaran. Seorang dapat menggunakan media dari hasil karyanya sendiri maupun hasil karya orang lain yang sesuai dengan kajian pembelajaran. Guru sebagai pengajar dikelas dapat mendesain media sesuai kebutuhannya. Pada dasarnya media pembelajaran yang digunakan menyangkut materi pelajaran yang diajarkan. Didalam media pembelajaran tersebut, tentunya harus diselingi materi-materi yang dapat menggugah semangat siswa selama mengikuti pelajaran (Rumidjan, 2017).

Media sebenarnya merupakan alat perantara yang berhubungan dengan komunikasi dua arah atau lebih yang didalamnya terdapat penerima dan pemberi pesan tersebut (Asyhar, 2011). Menurut (Anitah, 2012), media pembelajaran adalah alat atau penunjang yang digunakan dalam sistem pembelajaran dengan memperhatikan unsur-unsur pendukungnya. Tujuan dalam media pembelajaran sudah jelas sebagai penunjang aktivitas pembelajaran yang menghasilkan komunikasi dalam kegiatan belajar mengajar.

Ulead Video Studio 11 adalah aplikasi editing video yang sederhana dan bagus dalam meningkatkan pembelajaran di Sekolah. Ulead Video Studio 11 dapat diinstal di laptop dengan kapasitas ram yang standar. Semakin besar slot ram dan jenis laptop semakin mudah dalam menunjang aktivitas editing video pembelajaran. Adanya Ulead Video Studio 11, aktivitas guru akan meningkat. Ulead Video Studio 11 ini mampu mengkombinasikan unsur video, gambar, dan suara menjadi satu kesatuan. Didalamnya juga terdapat unsur pencerah bagi media yang akan didesain sedemikian rupa. Setelah media yang didesain melalui Ulead Video Studio 11 selesai, dapat dibuat menjadi MP4 yang dapat digunakan sebagai media pembelajaran (Sawiji, Heri, 2015).

Pelaksanaan pendidikan yang menggunakan media pembelajaran agar tetap efektif merupakan tujuan dari digunakannya sumber belajar tersebut. Semua materi yang akan diajarkan oleh guru dapat dikemas dengan baik sebagaimana mestinya. Media yang berkembang di era globalisasi, seperti multimedia semakin menyajikan sistem pembelajaran yang terbaik. Kombinasi unsur suara, gambar, animasi, dan lain-lainnya akan mempercantik media tersebut. Hal ini kemudian akan menjadikan siswa semakin nyaman dalam mengikuti pelajaran di kelas. Para siswa akan terfokus pada materi yang disajikan dengan baik. Inilah yang diharapkan dalam dunia pendidikan era modern. Arah pendidikan saat ini mengarah kepada kemajuan zaman yang semakin canggih. Elemen yang terdapat dalam multimedia dapat menggugah semangat dalam belajar siswa. selain itu, dapat membuat guru menjadi lebih aktif dan kreatif dalam berpikir meningkatkan kreativitasnya dimasa kini dan masa yang akan datang.

Unsur-unsur yang terkandung didalam multimedia seperti unsur warna, animasi, teks, dan lain sebagainya yang semuanya telah membuat pandangan menjadi lebih cerah dan menyenangkan. Dalam mengajar sangat diperlukan kolaborasi antar media dan pengajar agar dapat menghasilkan tujuan pembelajaran yang sesungguhnya. Dalam kegiatan pelatihan yang 
dilaksanakan pada dasarnya adalah untuk berbagai pengetahuan dan ilmu. Dari pengalaman yang didapatkan tim pemateri ini, akan bermanfaat bagi guru dan mahasiswa untuk meningkatkan kemampuan editing video melalui Ulead Video Studio 11. Pelatihan menggunakan aplikasi Ulead Video Studio 11 diharapkan dapat menambah wawasan para guru dan mahasiswa dalam meningkatkan pengetahuannya. Dalam mengajar di era globalisasi tidak cukup hanya mengandalkan teori saja tanpa praktik bagi guru. Untuk itu, pelatihan editing media pembelajaran dengan Ulead Video Studio 11 harus dimaksimalkan dengan baik (Hartono, 2018).

Pelatihan mendesain media pembelajaran dengan aplikasi Ulead Video Studio 11 ini dapat dimulai dengan terlebih dahulu melalui pengecekan kehadiran peserta. Pemateri setelah masuk ke dalam ruangan kemudian mencoba membuka materi yang akan dijelaskan. Terlihat dalam kegiatan ini para peserta sudah banyak yang siap dengan laptopnya. Oleh karena kesuksesan acara kegiatan pengabdian kepada masyarakat para peserta harus telah siap dengan laptopnya, maka peserta harus membawa sendiri laptopnya. Pemateri sambil memberikan materi pelatihan, kemudian memberikan aplikasi dan mulai mengintal aplikasi tersebut. Proses install sangat singkat, namun perlu dipahami kondisi laptop peserta harus dicek, agar tidak mengalami banyak kebingungan. Tentunya setelah aplikasi Ulead Video Studio 11 sudah terinstal dengan baik, pelatihan dilanjutkan dengan memberikan tutorial baik secara langsung maupun secara online. Dalam kegiatan pengabdian kepada masyarakat ini berlangsung selama 2 hari. Setelah dihari pertama pelaksanaan hanya sebatas mengenalkan dan proses install aplikasi, dihari kedua pelaksanaan dilaksanakan dengan praktik secara langsung. Dalam kegiatan hari kedua ini, banyak peserta kegiatan yang sudah mahir dalam mengoperasikan aplikasi (Ardiansyah, 2020).

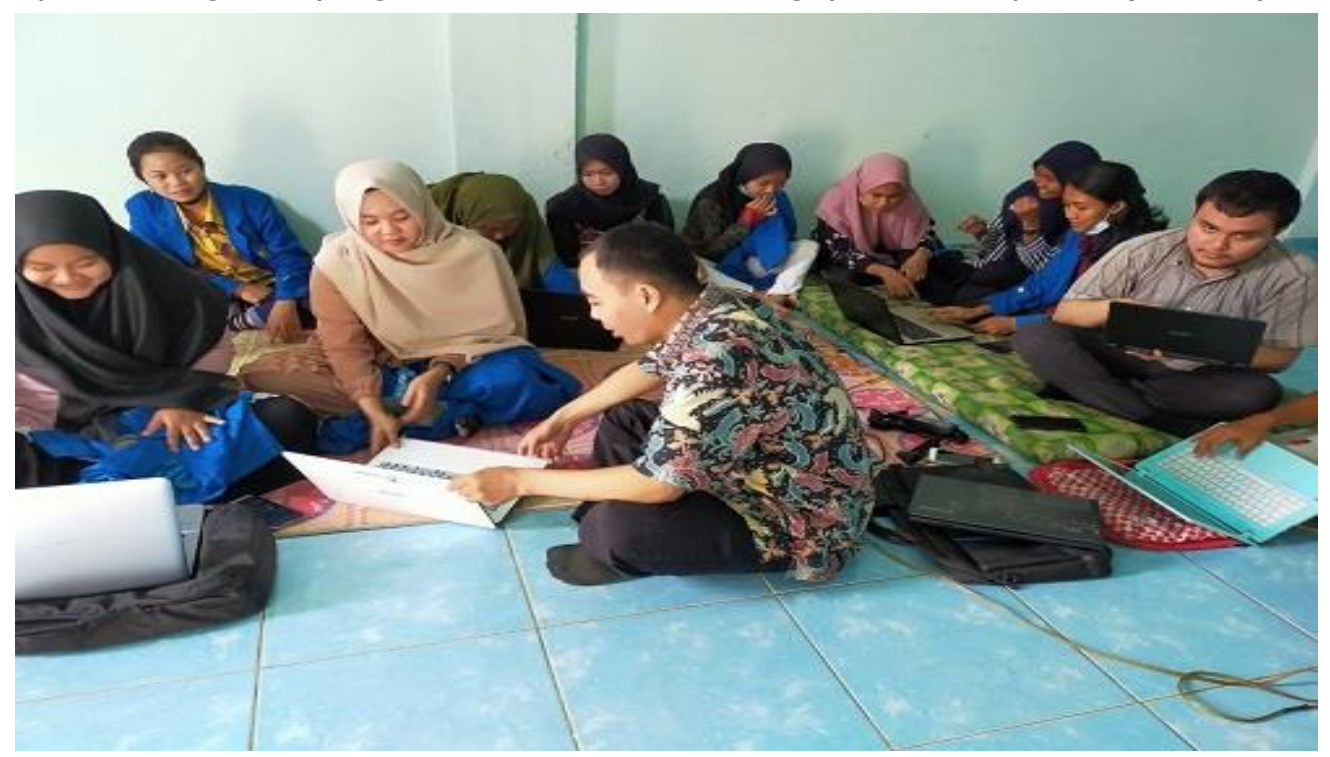




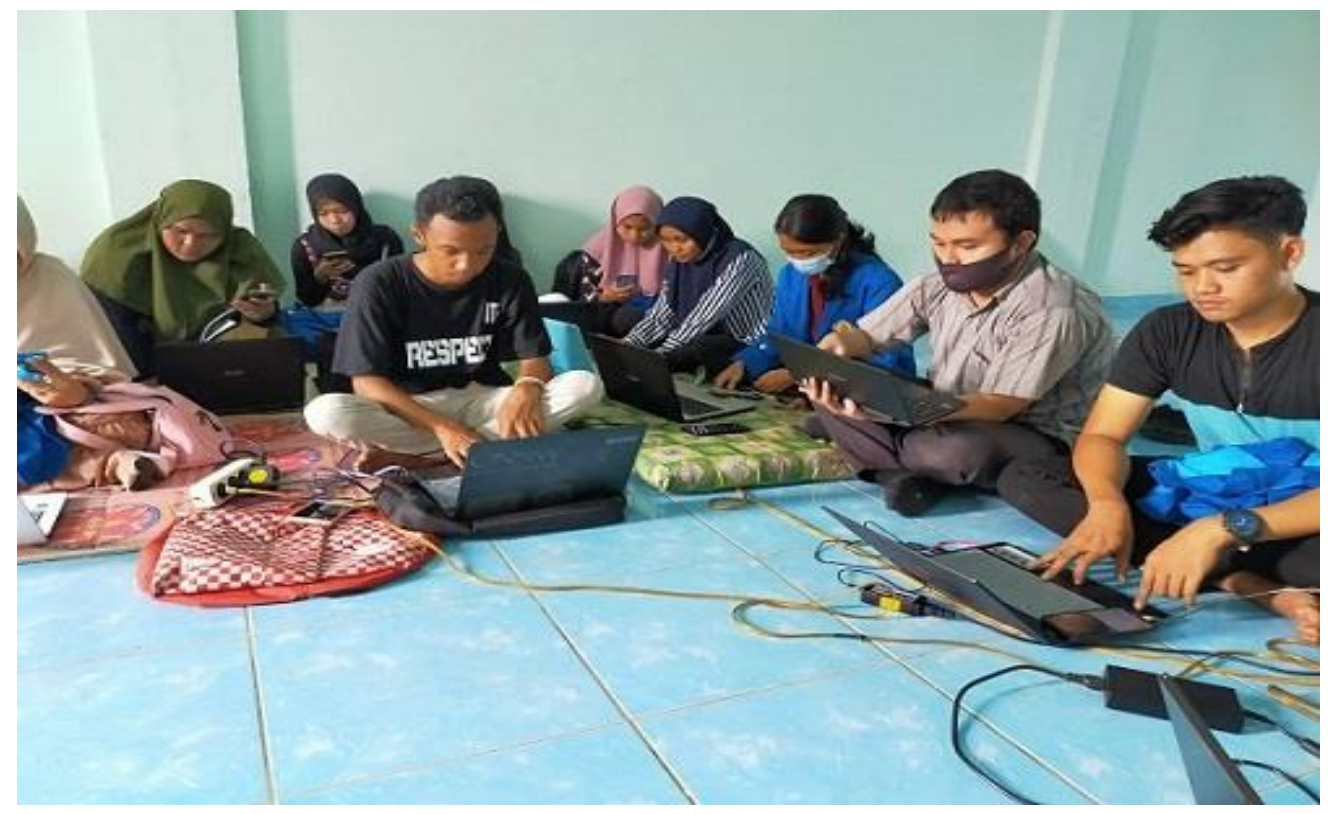

Gambar 1 \& 2 Pelatihan Mendesain Media dengan Aplikasi Ulead Video Studio 11

Kegiatan pelatihan dengan aplikasi Ulead Video Studio 11 ini berlangsung dengan sangat baik. Meskipun demikian, dalam pelaksanaannya terdapat beberapa kendala yang menjadi bahan evaluasi pelaksanaan pengabdian kepada masyarakat dimasa depan. Bahan evaluasi digunakan dalam rangkai sebagai mengukur barometer kemampuan peserta dalam menggunakan aplikasi Ulead Video Studio 11. Hal ini perlu diketahui bahwa, hal-hal yang menjadi kendala seperti kurang supportnya laptop peserta sampai pada sering lupanya peserta dalam menu-menu yang ada di aplikasi Ulead Video Studio 11 menjadi bahan evaluasi dimasa yang akan datang. Tidak lupa dalam pelaksanaan pelatihan mendesain media ini, pemateri tetap memberikan rangsangan berupa sesi tanya jawab terkait media yang sedang diajarkannya. Para peserta sangat antusias dalam kegiatan ini, sehingga ada timbal balik antara pemateri dan peserta kegiatan pengabdian kepada masyarakat. Pada dasarnya penggunaan aplikasi Ulead Video Studio 11 ini merupakan bagian dari multimedia yang sedang banyak berkembang dimasa kini.

Saat pelatihan selesai dilaksanakan, tentunya tim pelaksana yang terdiri dari pemateri melakukan evaluasi terkait pelaksanaan kegiatan selama ini. Hal-hal yang dinilai kurang sesuai dengan kegiatan harus diperbaiki kedepannya. Memang penggunaan aplikasi editing video seperti Ulead Video Studio 11 membutuhkan kesabaran yang besar. Disisi lain, support perangkat keras seperti laptop sangat besar sekali. Meskipun demikian, hasil dari editing media pembelajaran yang digunakan akan semakin maksimal. Melalui analisis tim dalam kegiatan ini, tentunya berdampak positif dengan penambahan kemampuan dan pengalaman dari guru-guru SMP dan para siswa selama mengikuti kegiatan ini. masukan-masukan dari penyelenggara kegiatan terkait kegiatan lanjutan tentunya menjadi pertimbangan tim pelaksana dan pemateri untuk kegiatan serupa dimasa yang akan datang. Pada dasarnya, pemateri selalu berpesan kepada peserta untuk terampil dalam menggunakan media pembelajaran dan memaksimalkan 
teknologi untuk hal yang membangun dunia pendidikan.

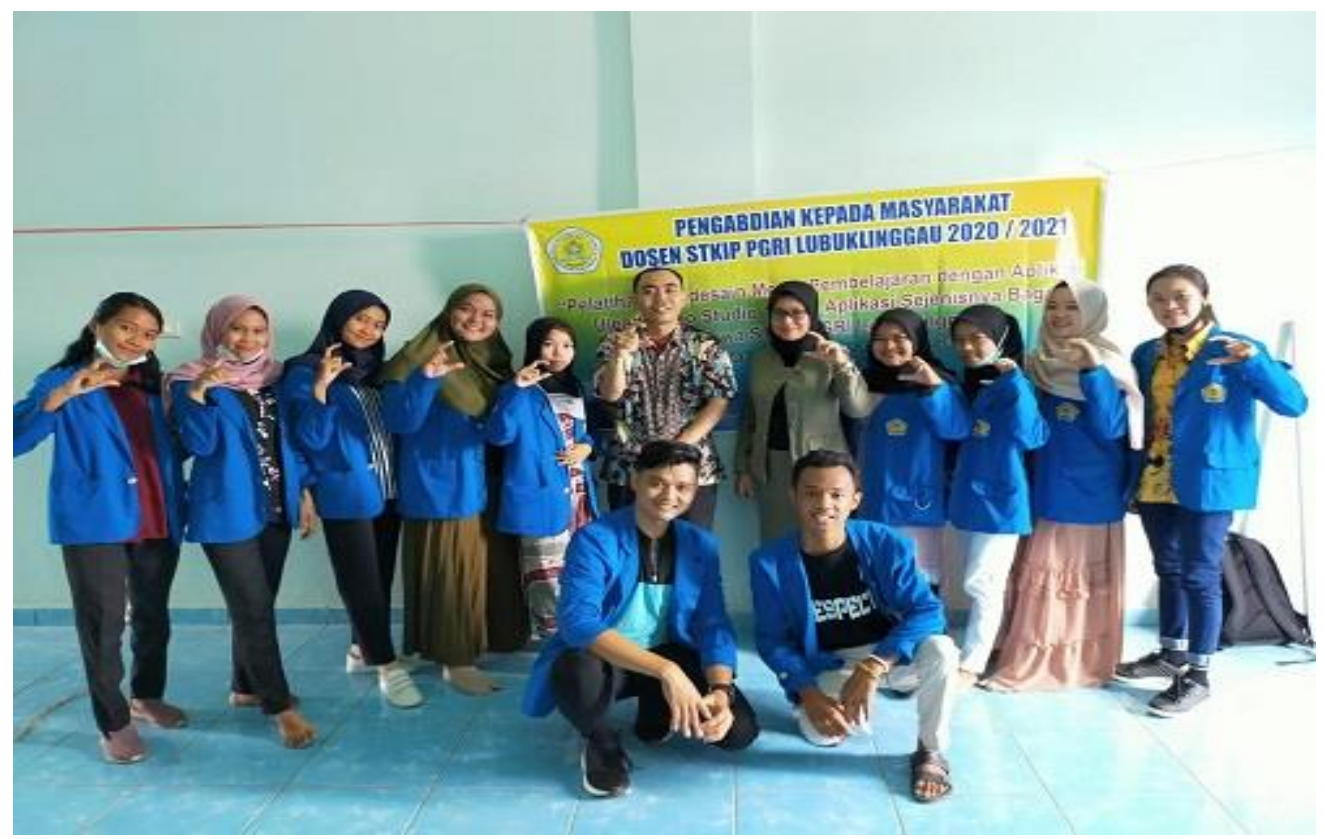

Gambar 3. Dosen Pelaksana Kegiatan PKM Berfoto Bersama Guru dan Mahasiswa

Pada dasarnya yang berlangsung dengan melibatkan guru SMP dan mahasiswa di Lubuklinggau melalui kegiatan PKM ini yang mengambil tema dengan "Pelatihan mendesain media pembelajaran dengan aplikasi Ulead Video Studio 11 dan aplikasi sejenisnya bagi mahasiswa STKIP-PGRI Lubuklinggau" ini mendapat semangat antusias yang sangat tinggi dari para peserta pelatihan. Pelatihan pembuatan media ini sangat baik dilaksanakan ditengah pembelajaran jarak jauh yang mampu lebih efesien dimasa saat ini. para peserta pelatihan yang belum memahami secara benar, masih dibimbing sampai benar-benar mampu mengoperasikan sendiri media editing tersebut. Salah satu yang menjadi motivasi kami dalam melaksanakan pengabdian kepada masyarakat saat ini adalah antusias peserta yang sangat tinggi. Meskipun demikian, tim pelaksana pengabdian kepada masyarakat tetap membatasi peserta agar tetap menjaga diri dari penyebaran virus Corona meskipun telah masuk dalam era new normal ini.

Harapan kami dalam kegiatan pengabdian kepada para peserta pelatihan yang penuh semangat ini dapat dapat dilakukan kembali dan bagi peserta untuk tetap tidak puas diri dalam terus mengembangkan inovasinya ditengah wabah covid 19 saat ini. Para peserta yang sebagian adalah mahasiswa yang memiliki aktivitas sebagai pengajar di sekolah, dapat menerapkan kembali media yang telah dipelajari dari pelatihan tersebut. Selain itu, para peserta untuk tetap mau menjunjung tinggi semangat belajar untuk mengembangkan keilmuannya. Dimasa pandemik saat ini banyak pelatihan-pelatihan online yang murah. Harapan kami tim pengabdian kepada masyarakat, para peserta untuk mengikuti pelatihan tersebut saat memiliki waktu pengembangan diri. 


\section{SIMPULAN}

Dari hasil pengabdian kepada masyarakat dapat dilihat dengan adanya semangat dan antusiasme peserta yang mengikuti pelatihan sangat tinggi. Pelatihan mendesain media harus dilaksanakan secara rutin dan dilakukan oleh semua unsur Dosen dilingkungan STKIP PGRI Lubuklinggau. Pelatihan mendesain media ini bertujuan sebagai membekali peserta agar lebih aktif dan kreatif dalam mendesain media dan menerapkannya pada lingkungan kerja maupun kuliah. Dalam kegiatan pengabdian kepada masyarakat ini diikuti oleh 15 peserta yang terdiri dari mahasiswa dan guru SMP di Kota Lubuklinggau. Peserta yang hadir merespon dan menyambut positif kegiatan yang dilaksanakan oleh tim pengusul dan sebagian peserta juga mengusulkan untuk diadakan kegiatan lanjutan.

\section{UCAPAN TERIMA KASIH}

Ucapan terima kasih penulis kepada tim yang telah terlibat dalam kegiatan pengabdian kepada masyarakat dengan tema Pelatihan Membuat Media Pembelajaran dengan Aplikasi Ulead Video Studio 11 Bagi Guru SMP dan Mahasiswa Kota Lubuklinggau, yaitu:

1. Lembaga STKIP PGRI Lubuklinggau yang telah memberikan izin dan fasilitas kegiatan selama pengabdian kepada masyarakat.

2. Ibu Dr. Ratna Wulansari, M.Pd., yang telah membantu menjadi narasumber kegiatan pengabdian kepada masyarakat.

3. Guru-guru SMP di Kota Lubuklinggau yang antusias dalam mengikuti kegiatan pengabdian kepada masyarakat yang kami laksanakan.

4. Para mahasiswa yang mengikuti kegiatan pengabdian kepada masyarakat dan membantu dalam pelaksanaannya.

5. Komunitas Sahabat Pelestari Sejarah Seni dan Budaya Lubuklinggau yang telah membantu dalam pelaksanaan kegiatan pengabdian kepada masyarakat.

\section{REFERENSI}

Anitah, S. (2012). Media Pembelajaran. Yuma Pustaka.

Ardiansyah, A. \& K. A. (2020). Pelatihan Merancang dan Mengembangkan Multimedia Pembelajaran untuk Guru di SD Negeri Bajangan Kabupaten Pasuruan. Amalee: Indonesian Journal of Community Research and Engagement, 1(2), 125-137. https://doi.org/10.37680/amalee.v1i2.368

Asyhar, R. (2011). Kreatif Mengembangkan Media Pembelajaran. Gaung Persada (GP) Press Jakarta.

Hartono, D. (2018). Pelatihan dan Pendampingan Pembuatan Media Pembelajaran Berbasis Multimedia Interaktif. Jurnal Tranformas, 14(2), 139-147. https://doi.org/http://dx.doi.org/10.29406/al-khidmah.v1i2.1216

Haryadi, R. N., Rojali, A., \& Fauzan, M. (2021). Sosialisasi Penggunaan Online Shop berbasis Website di UMKM CImanggis. 1(1), 10-16.

Hasan, S. H. (2019). Said Hamid Hasan Pendidikan Sejarah untuk Kehidupan Abad Ke 21 
M. HISTORIA: Jurnal Pendidik Dan Peneliti Sejarah, II(2), 61-72.

https://doi.org/https://doi.org/10.17509/historia.v2i2.16630

Rumidjan, D. (2017). Pelatihan Pembuatan Media Pembelajaran Untuk Meningkatkan

Kualitas Pembelajaran Bagi Guru Sekolah Dasar. ABDIMAS PEDAGOGI, 1(1), 77-81.

https://doi.org/http://dx.doi.org/10.17977/um050v1i1p\%25p

Sawiji, Heri, dkk. (2015). Kombinasi Format Factory, U-Lead dan Microsoft Office

Powerpoint Dalam Upaya Meningkatkan Kualitas Media Pembelajaran (pp. 1-6).

Prosiding Semiar Nasional Pendidikan Ekonomi \& Bisnis Fakultas Keguruan dan Ilmu Pendidikan Universitas Sebelas Maret Surakarta.

Sriyanti, ida, dkk. (2015). Pelatihan Pembuatan Media Pembelajaran Berbasis E-Learning Bagi Guru SMA Srijaya Negara Palembang. JURNAL INOVASI DAN PEMBELAJARAN FISIKA, 2(1), 12-18. https://doi.org/https://doi.org/10.36706/jipf.v2i1.2349

Wulandari, Ika, dkk. (2015). Pengaruh Media Ulead Video Terhadap Hasil Belajar Peserta Didik Pada Mata Pelajaran Ekonomi di SMA PGRI Gelumbang. Jurnal PROFIT Kajian Pendidikan Ekonomi Dan IImu Ekonomi, 2(2), 179-185.

https://doi.org/https://doi.org/10.36706/jp.v2i2.5547 